\title{
The micro-propagation study of Eryngium foetidum, L using various plant growth regulators
}

\author{
Deepa K $\mathrm{P}^{1}$ \\ (Assistant Professor ${ }^{1}$ ) \\ Department of Botany ${ }^{1}$, Bishop Heber College (Autonomous), Tiruchirappalli ${ }^{1}$ \\ Email: deepacck@gmail.com ${ }^{1}$
}

\begin{abstract}
Plant tissue culture provides a medium for the rapid growth and multiplication of economically important plants. It helps to develop mass amount of plantlets in a specific time and for bulk utilization. In the present study one medicinal plant, Eryngium foetidum, L was taken for the in vitro propagative study using various plant growth regulators. The shoot tips and leaf segments of Eryngium foetidum L were selected as explants for culture initiation. Different combination of selected auxin, NAA and cytokinin, BA were supplemented to the MS medium to assess the in vitro responses. High concentration of BA $(6 \mathrm{mg} / \mathrm{L})$ has produced best results by producing 6-8 shoot buds in shoot tip segments. Multiple shoots were produced at BA and BA with NAA. But BA above $8 \mathrm{mg} / \mathrm{L}$ reduce the shoot proliferation.
\end{abstract}

Keywords- In-vitro propagation; MS medium; NAA; BA; plant hormones.

\section{INTRODUCTION}

Plants are being used as a major source for the making of medicines from the past more than thousands of years. As per the estimation made by the World Health Organization, about $80 \%$ of the people are still relying mainly on the traditional medicines such as herbs for their medicinal needs even today. Plants are also being used as an important source of numerous modern medicines. As per the estimation, roughly one quarter of prescribed drug contains plant extracts / active ingredients took from the plant elements. In vitro propagation techniques are increasingly being used for the rapid vegetative propagation (Deepa, 2019). The sole objective of totipotency of differentiated plant cells now finds application in both basic and applied researches in various fields.

Direct and high frequency somatic embryogenesis and plant regeneration from the hypocotyls of chickpea (Cicer arietinum, L.) a grain legume was reported by Kiran et al., 2005. Axillary shoot tip explants have been used for the in vitro regeneration and bulk production of two Capsicum annum, Linn. Shoot tip explants cut out from laboratory raised sprouts have been used for multiple shoot bud initiation in the MS medium enhanced with BAP (only) or with a mixture of IAA (Keithellakpam Sanatombi and Gurumayam Jitendra Sharma; 2006)

In the present study, Eryngium foetidum, L. is selected. It is a biennial herb. It comprises of more than two hundred temperate and tropical species (Willis, 1960). The leaf margin of Eryngium foetidum, $\mathrm{L}$ is toothed and every serration of the border contains a minor spine with yellowish color. These plants bear a clustered and well branched spike inflorescence developing the characteristics of umbel inflorescence on a lengthy stalk emerging from the axis of leaf rosette (Morton, 1981 and Moran, 1988). The calyx is green in color whereas the corolla is creamy white. Eryngium foetidum, $\mathrm{L}$. is first reported from West Indies and North America (Adams, 1971). Eryngium foetidum, L. develops naturally all over several Caribbean islands which includes Toboga and Trinidad. This herbs are usually found alongside shaded or moist paths as well as nearby cultivated zones wherein heavy soils predominate (Seaforth et al., 1983, Morean, 1988).

Eryngium foetidum, L., has sharply strong smell (pungent). Due to this fragrance resemblance, the leaves are being used interchangeably in various food preparations. In Thailand, Malaysia and Singapore where it is commonly used to making soups, noodle dished and curries. The fresh herb is used for making spiced paste. Eryngium foetidum is reported to be rich in Riboflavin, Carotene, Iron, and Calcium. Fresh leaves are of $1.7 \%$ Ash, 6.5\% Carbohydrate, $0.6 \%$ fat, $3.3 \%$ Protein, $86-88 \%$ moisture, $0.02 \%$ Iron and $0.06 \%$ Phosphorus. Leaves are tremendous source of vitamin A, B, B2 and C (Bautista et al.1988). On a dry weight basis, leaves contains $27.7 \%$ Crude fiber, 1.23\% Calcium, 0.1 $0.95 \%$ Volatile oil, and $23 \mathrm{ppm}$ Boron. Another major application of leaves is as medicines for diarrhea, vomiting, fevers and chills, and in Jamaica for colds and convulsions in children (Honeychurch, 1980).

\section{MATERIALS AND METHODS}

Culture medium chosen for the present study was Murashige and Skoog (MS) medium. This medium is composed of inorganic salt, an iron source, vitamins, amino acids, hormones and carbohydrate supply. Sucrose was used as the carbohydrate and agar-agar was the gelling reagent. The $\mathrm{pH}$ of the culture medium 


\section{Available online at www.ijrat.org}

had been positioned to 5.6 to 5.8 before adding agar. In the present study, NAA was used as auxin and BA was used as cytokinin. sterilized explants were kept in air flow chamber in closed glass vessel.

Introduction of explants in to the culture
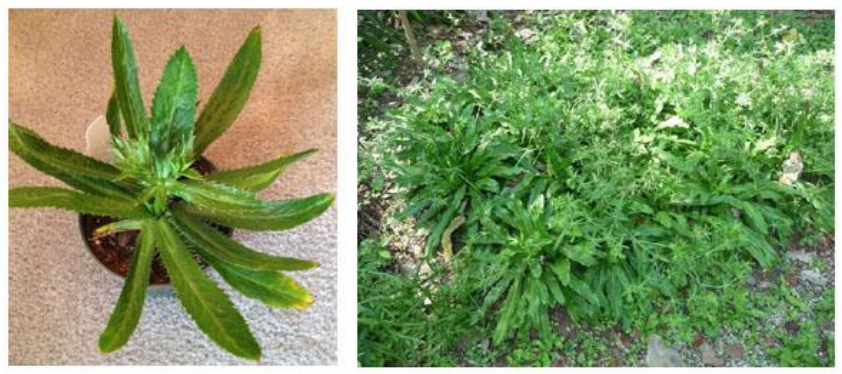

Fig. 1. Eryngium foetidum, L- Habit

Add stock solution in required volume in the beaker. Add sucrose and meso inositol to it and mixed well. The $\mathrm{pH}$ is adjusted to 5.8 using a $\mathrm{pH}$ meter with a few drops of either $\mathrm{IN} \mathrm{NaOH}$ or $\mathrm{HC} 1$. Add required amount of growth regulators to the mixture. In order to make the medium solid, add required amount of agar and the mixture is made up to 1 liter using distilled water. The mixture is heated to $600 \mathrm{C}$ to dissolve the agar. The medium is carefully transferred to sterilized culture tubes and tightly plugged with sterile nonabsorbent cotton plugs. The medium is finally sterilized by autoclaving at $1210 \mathrm{C}$ for 20 minutes in an autoclave. The autoclaved medium is allowed to cool and now the medium became jelly. It is kept on a clean place at room temperature. Plant growth regulators, cytokinins such as benzyl adenine (BA), and auxins, naphthalene Acetic acid (NAA), were dissolved in few drops of $\mathrm{NaOH}$ or ethanol and make up to desired volume with distilled water and stored at 4o C.

The shoot tip and leaf segments from healthy plants, were dissected out from surface sterilized plant material used for experimental purposes. The explants should be free of contaminations. The explants should be surface sterilized before use.

\subsection{Procedure}

The shoot tip and leaf segments from healthy plants were cleaned by washing carefully in running tap water for removing mud, dust, etc. To remove surface contaminants, the explants are shaken well for five minutes in $0.1-1 \%$ leboline and kept in running tap water for a period of about $1 \mathrm{Hr}$ to remove surface contaminants and trances of detergent. The explants have been surface sterilized by $0.1 \% \mathrm{Hgcl}_{2}$ for five minutes. After each treatment the explants have been washed 2-4 times using sterile distilled water for removing the sterilant (Table-1). All these were done in the sterile condition of laminar airflow. The medium is called inoculation and done in laminar air flow cabinet. The instrument is provided with High Efficiency Particulate Air filter (HEPA) which removes particles that are bigger than 0.3 micron. The ultra-purified air is passed though the cabin at a velocity of $27+3 \mathrm{~m} / \mathrm{min}$. Thus, the entry of microbes in to the cabinet is sterilized by $100 \%$ ethyl alcohol to ensure absolute sterility. Cotton plug of the sterilized culture tube containing the medium is carefully removed and the explain is carefully inoculated on the medium by using a sterilized forceps. The tip of the leaf segments and shoot tip were trimmed by cutting the basal exposed portion before inoculations. The mouth of the culture tube is gently heated and replace the cotton plug tightly. All these processes were inside the laminar airflow.

After the inoculation the explants in the culture media were incubated in a sterile culture room under controlled condition of temperature, light and humidity. The cultures were incubated on culture rack at $200-250 \mathrm{C}$.

\section{RESULTS AND DISCUSSION}

The shoot tip was inoculated to the MS medium along with BA hormone and the combination of BA and NAA. The shoot tip treated using $2 \mathrm{mg} / \mathrm{L}$, $\mathrm{BA}$ resulted in elongation of shoot. While the concentration of BA was changed to $4 \mathrm{mg} / \mathrm{L}, 2-3$ shoots produced and at $5 \mathrm{mg} / \mathrm{L}$, BA $5-6$ shoots developed and when BA changed to $6 \mathrm{mg} / \mathrm{L}, 6-8$ shoots were produced (Fig. 2.a). The concentration of BA was above $8 \mathrm{mg} / \mathrm{L}$ the number of shoot was significantly reduced (Fig. 2.b). The mixture of BA, $2 \mathrm{mg} / \mathrm{L}$ and NAA, $1 \mathrm{mg} / \mathrm{L}$ indicates the multiple shoots in lesser numbers. At, $2 \mathrm{mg} / \mathrm{L} 4$ and mg/L BA NAA, 68 shoot bus were produced with thick roots (Fig 2.c). The concentration of BA $6 \mathrm{mg} / \mathrm{L}$ and $2 \mathrm{mg} / \mathrm{L}$ NAA increases the number of shoots. Though the roots also developed in these concentration, they were short and 


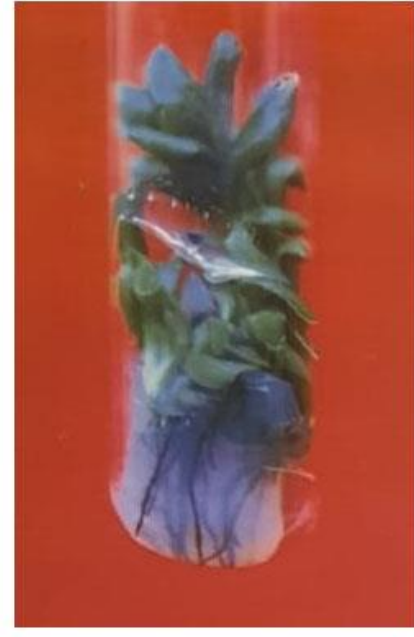

Fig. 2a $6 \mathrm{mg} / \mathrm{L} \mathrm{BA}$



Fig. $2 \mathrm{c} 4 \mathrm{mg} / \mathrm{L}$ BA and $2 \mathrm{mg} / \mathrm{L}$ NAA

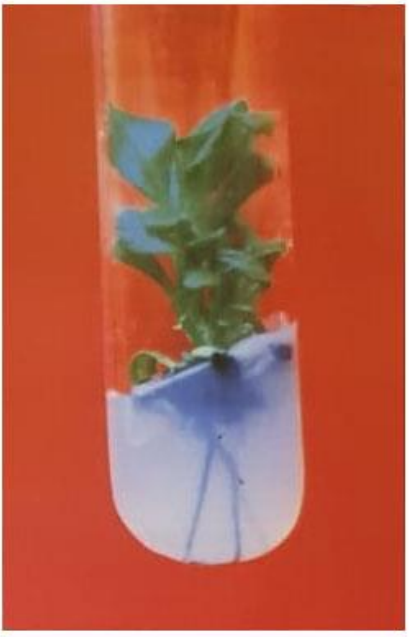

Fig. $2 \mathrm{~b} \quad 8 \mathrm{mg} / \mathrm{L} \mathrm{BA}$



Fig. $2 \mathrm{~d} \quad 8 \mathrm{mg} / \mathrm{L} \mathrm{BA}$ and $4 \mathrm{mg} / \mathrm{L} \mathrm{NAA}$

Fig. 2. Organogenesis of Eryngium foetidum, L at various composition.

thick. The concentration of NAA $(4 \mathrm{mg} / \mathrm{L})$ and BA $(8 \mathrm{mg} / \mathrm{L})$ reduced the number of shoot development (Fig. 2.d). The response to various plant hormones were tabulated in Table-2.

Callus development was seen on the cut ends of leaf segments. Leaf segment supplemented with $2 \mathrm{mg} / \mathrm{L}$ BA, callus was initiated (Fig. 3.a). BA when changed to $4 \mathrm{mg} / \mathrm{L}$, shoot buds initiated from the callus. The concentration of BA $6 \mathrm{mg} / \mathrm{L}$, initiate $6-8$ shoot bud from the callus (Fig. 3.d). BA was changed to $8 \mathrm{mg} / \mathrm{L}, 10-12$ shoots produced. When the concentration of BA was above $10 \mathrm{mg} / \mathrm{L}$, the number of shoot buds are significantly reduced. The combination of BA $(4 \mathrm{mg} / \mathrm{L})$ and NAA $(2 \mathrm{mg} / \mathrm{L})$ initiate callus multiplication (Fig. 3.b). shoot buds were developed from the callus cultured in $2 \mathrm{mg} / \mathrm{L}$ NAA and $6 \mathrm{mg} / \mathrm{L} \mathrm{BA} \mathrm{(Fig} \mathrm{3.c).} \mathrm{At} \mathrm{NAA} \mathrm{(4} \mathrm{mg/L)} \mathrm{and}$
BA $(8 \mathrm{mg} / \mathrm{L}), 8-10$ shoot buds were produced. The concentration of NAA $(6 \mathrm{mg} / \mathrm{L})$ and BA $(10 \mathrm{mg} / \mathrm{L})$ the shoot buds show significant reduction.

Table-1. Rate of sterilization of explants

\begin{tabular}{|l|c|c|c|}
\hline $\begin{array}{l}\text { HgCl2 } \\
\text { used } \\
(\%)\end{array}$ & $\begin{array}{c}\text { Time of } \\
\text { HgCl2 } \\
\text { used } \\
\text { (mints) }\end{array}$ & $\begin{array}{c}\text { Survival } \\
\text { rate }\end{array}$ & $\begin{array}{c}\text { Contamination } \\
(\%)\end{array}$ \\
\hline 0.05 & 3 & 20 & 80 \\
\hline 0.05 & 5 & 35 & 65 \\
\hline 0.1 & 5 & 90 & 10 \\
\hline 0.1 & 10 & 0 & $\begin{array}{c}\text { No } \\
\text { development }\end{array}$ \\
\hline
\end{tabular}






Fig. 3a $2 \mathrm{mg} / \mathrm{L} \mathrm{BA}$

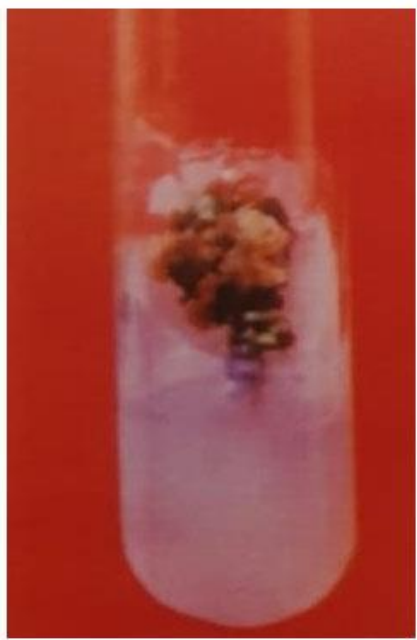

Fig. $3 \mathrm{c} \quad 6 \mathrm{mg} / \mathrm{L} \mathrm{BA}$ and $2 \mathrm{mg} / \mathrm{L}$ NAA

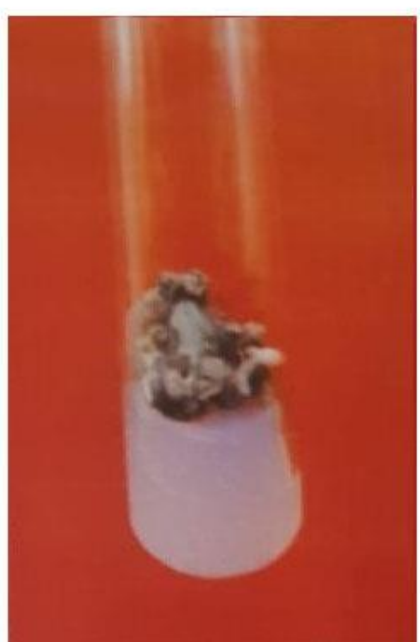

Fig. $3 \mathrm{~b} \quad 4 \mathrm{mg} / \mathrm{L} \mathrm{BA}$ and $2 \mathrm{mg} / \mathrm{L} \mathrm{NAA}$

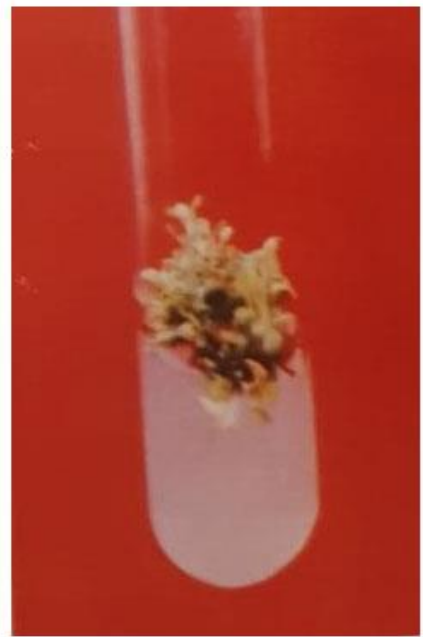

Fig. $3 \mathrm{~d} 6 \mathrm{mg} / \mathrm{LBA}$

Fig. 3. Picture showing Callus proliferation in various composition.

High concentration of BA $(6 \mathrm{mg} / \mathrm{L})$ has produced best results by producing 6-8 shoot buds in shoot tip segments. Multiple shoots were produced at BA and $\mathrm{BA}$ with NAA. But BA above $8 \mathrm{mg} / \mathrm{L}$ reduce the shoot proliferation. In low concentration of auxin $(1 \mathrm{mg} / \mathrm{L})$, with cytokinine (2 $\mathrm{mg} / \mathrm{L} \mathrm{BA})$, long and slender roots developed and became short and thick by the increasing concentration of NAA $(6 \mathrm{mg} / \mathrm{L})$, but NAA above $6 \mathrm{mg} / \mathrm{L}$, little roots were developed. Root hairs never formed in any of the hormones used. B.A $(8 \mathrm{mg} / \mathrm{L})$ with NAA (4 mg $/ \mathrm{L})$ produced more shoot buds regenerated from the callus. At concentration 6 $\mathrm{mg} / \mathrm{L} \mathrm{NAA}$ and $10 \mathrm{mg} / \mathrm{L}$ BA reduced the number of shoot buds regenerated from the callus (Table- 3 ).
Table-2. Response to different plant hormones when shoot tip used as explant 
Available online at www.ijrat.org

\begin{tabular}{|r|c|c|l|}
\hline Medium & $\begin{array}{l}\text { BA } \\
(\mathbf{m g} / \mathbf{l})\end{array}$ & $\begin{array}{l}\text { NAA } \\
(\mathbf{m g} / \mathbf{l})\end{array}$ & Response \\
\hline \multirow{5}{*}{ MS } & 2 & - & Initiation of shoot \\
\cline { 2 - 4 } & 4 & - & $2-3$ shoot bud \\
\cline { 2 - 4 } & 5 & - & 6 shoot bud \\
\cline { 2 - 4 } & 6 & - & 8 shoot bud \\
\cline { 2 - 4 } & 8 & - & 2-3 shoot bud \\
\cline { 2 - 4 } & 2 & 1 & $\begin{array}{l}\text { Initiation of multiple shoot } \\
\text { with slender roots }\end{array}$ \\
\cline { 2 - 4 } & 4 & 2 & $\begin{array}{l}\text { 6-8 multiple shoots with } \\
\text { thick roots }\end{array}$ \\
\cline { 2 - 4 } & 6 & 2 & $\begin{array}{l}\text { 8-10 shoot bud with short } \\
\text { and stout roots }\end{array}$ \\
\cline { 2 - 4 } & 6 & 4 & 2-3 shoot without roots \\
\cline { 2 - 4 } & 8 & &
\end{tabular}

[5] Morton J F, Umbelliferae In. Atlas of medicinal plants of middle America. Sprringfield Illinois: CC Thomas, 1981.

[6] Sea forth C E, Eryngium foetidium -ftit weed (umbelliferae), In. Natural Products in Carribean folk medicine, 1988 .

[7] Wills J C, A dictionary of flowering plants and fern. Cambridge University Press Cambridge, 1960.

Table-3. Response to different plant hormones when leaf segments used as explants.

\begin{tabular}{|c|c|c|l|}
\hline M e d i u m & $\begin{array}{l}\text { BA } \\
(\mathrm{mg} / \mathrm{l})\end{array}$ & $\begin{array}{l}\text { NAA } \\
(\mathrm{mg} / \mathrm{l})\end{array}$ & Response \\
\hline \multirow{6}{*}{} & 2 & - & Callus initiation \\
\cline { 2 - 4 } & 4 & - & Initiation of shoot buds \\
\cline { 2 - 4 } & 5 & - & 4-6 shoot buds \\
\cline { 2 - 4 } & 6 & - & 6-8 shoot buds \\
\cline { 2 - 4 } & 8 & - & $10-12$ shoot buds \\
\cline { 2 - 4 } & 10 & - & 2-4 shoot buds \\
\cline { 2 - 4 } & 2 & 1 & No response \\
\cline { 2 - 4 } & 4 & 2 & $\begin{array}{l}\text { Initiation of callus } \\
\text { multiplication }\end{array}$ \\
\cline { 2 - 4 } & & 2 & 6-8 shoot buds \\
\cline { 2 - 4 } & 6 & 4 & $12-14$ shoot buds \\
\cline { 2 - 4 } & 8 & 6 & 2-4 shoot buds \\
\cline { 2 - 4 } & 10 & & \\
\hline
\end{tabular}

\section{ACKNOWLEDGEMENT}

I express my gratitude to all my professional friends, colleagues and teachers who helped me with proper advice in clarifying the doubts related to this area.

\section{REFERENCES}

[1] Adams C D, Flowering Plants of Jamaica University. West Indies. Mona, Jane, 1971.

[2] Deepa K P, In vitro Studies of Ocimum sanctum using various plant growth regulators. Zenith International Journal of Multidisciplinary Research. Volume 9: 252-257, 2019.

[3] Honey Church P N, Carribean wild plant and their uses. Letch Worthpress, Barbados, W.I., 1980

[4] Kiran G, Kaviraj C P, Jogeswar G, Kavi Kishor P B and Srinath Rao 92005). Direct and high frequency somatic embryogenesis and plant regeneration from hypocotyls of chick pea. Current Science Vol 89; 1012-1018 